\title{
Trace element cycling in a subterranean estuary: Part 2. Geochemistry of the pore water
}

\author{
Matthew A. Charette* and Edward R. Sholkovitz \\ Department of Marine Chemistry and Geochemistry \\ Woods Hole Oceanographic Institution \\ Woods Hole, Massachusetts 02543 USA
}

\author{
Submitted to: \\ Geochimica et Cosmochimica Acta
}

May 2, 2005

In revised form:

September 2, 2005

*corresponding author: e-mail, mcharette@whoi.edu; tel, 508-289-3205; fax, 508-457-2193 


\begin{abstract}
Submarine groundwater discharge (SGD) is an important source of dissolved elements to the ocean, yet little is known regarding the chemical reactions that control their flux from sandy coastal aquifers. The net flux of elements from SGD to the coastal ocean is dependent on biogeochemical reactions in the groundwater-seawater mixing zone, recently termed the "subterranean estuary". This paper is the second in a two part series on the biogeochemistry of the Waquoit Bay coastal aquifer/subterranean estuary. The first paper addressed the biogeochemistry of $\mathrm{Fe}, \mathrm{Mn}, \mathrm{P}, \mathrm{Ba}, \mathrm{U}$, and $\mathrm{Th}$ from the perspective of the sediment composition of cores (Charette et al., 2005). This paper uses pore water data from the subterranean estuary, along with Bay surface water data, to establish a more detailed view into the estuarine chemistry and the chemical diagenesis of $\mathrm{Fe}, \mathrm{Mn}, \mathrm{U}, \mathrm{Ba}$ and $\mathrm{Sr}$ in coastal aquifers.

Nine high-resolution pore water (groundwater) profiles were collected from the head of the bay during July 2002. There were non-conservative additions of both $\mathrm{Ba}$ and $\mathrm{Sr}$ in the salinity transition zone of the subterranean estuary. However, the extent of Sr release was significantly less than that of its alkaline earth neighbor Ba. Pore water Ba concentrations approached $3000 \mathrm{nM}$ compared with 25-50 nM in the surface waters of the bay; the pore water Sr-salinity distribution suggests a $26 \%$ elevation in the amount of Sr added to the subterranean estuary. The release of dissolved $\mathrm{Ba}$ to the mixing zone of surface estuaries is frequently attributed to an ion-exchange process whereby seawater cations react with $\mathrm{Ba}$ from river suspended clay mineral particles at low to intermediate salinity. Results presented here suggest that reductive dissolution of Mn oxides, in conjunction with changes in salinity, may also be an important process in maintaining high concentrations of $\mathrm{Ba}$ in the pore water of subterranean estuaries.

In contrast, pore water $U$ was significantly depleted in the subterranean estuary, a result of SGD-driven circulation of seawater through reducing permeable sediments. This finding is supported by surface water concentrations of $U$ in the bay, which were significantly depleted in U compared with adjacent coastal waters. Using a global estimate of SGD, we calculate U removal in subterranean estuaries at $20 \times 10^{6} \mathrm{~mol} \mathrm{U} \mathrm{y}^{-1}$, which is the same order of magnitude as the other major $U$ sinks for the ocean. Our results suggest a need to revisit and reevaluate the oceanic budgets for elements that are likely influenced by SGD-associated processes.
\end{abstract}




\section{INTRODUCTION}

Important geochemical processes on the earth occur at interfaces. One major interface that has received limited attention is the groundwater-seawater mixing zone beneath coastlines. The potential importance of this boundary led Moore (1999) to introduce the concept of a "subterranean estuary", which he defined as the mixing zone between terrestrially-derived fresh groundwater and seawater in a coastal aquifer. Geochemical budgets associated with water transport and reactions in subterranean estuaries are poorly constrained, mainly because they are difficult interfaces from which to collect samples (Burnett et al., 2001, 2002). Recent studies indicate that groundwater-seawater interactions in subterranean estuaries may be important sources of $\mathrm{Ba}, \mathrm{Ra}$ and $\mathrm{Sr}$ to the ocean; the oceanic budgets of these and other inorganic elements need to be reevaluated with respect to processes in subterranean estuaries (Moore, 1996; Shaw et al., 1998; Basu et al., 2001).

A series of papers have argued that the transport of $\mathrm{Ba}$ and $\mathrm{Ra}$ by submarine groundwater discharge (SGD) can account for a significant fraction of the elevated concentrations of Ba and Ra observed in many estuaries and shelf waters (Moore, 1996, 1997, 1999; Moore and Shaw, 1998; Shaw et al., 1998). These papers suggest that there are two biogeochemical processes responsible for elevating the concentrations of $\mathrm{Ba}$ and $\mathrm{Ra}$. The first process involves the release of $\mathrm{Ba}$ and $\mathrm{Ra}$ to the dissolved phase by ion exchange reactions during the landward intrusion of seawater into coastal aquifers. Shaw et al. (1998) and Moore (1999) also suggest that the release of dissolved $\mathrm{Ba}$ and $\mathrm{Ra}$ to coastal aquifers via SGD may be driven by the redox cycles of iron and manganese oxides. The underlying mechanism in this scenario is the adsorption of $\mathrm{Ra}$ and $\mathrm{Ba}$ onto the metal oxides under oxic conditions and their release under sub-oxic or anoxic conditions to discharging submarine groundwater.

In a study of strontium in the Ganges-Brahamaputra (G-B) delta, Basu et al. (2001) concluded that SGD was a potential source of strontium to the oceans equal in magnitude to the dissolved Sr concentrations carried to the oceans by the G-B river water. They also suggested that their estimate of SGD-derived Sr was significant enough to have a major effect on the $\mathrm{Sr}$ 
isotope composition of seawater. Hence, the geochemical cycles of three widely-applied alkaline earth elements (Ba, $\mathrm{Ra}$ and $\mathrm{Sr}$ ) may be influenced by reactions and flow in subterranean regions near estuaries and coasts.

This paper is the second of a two part series in this journal on the biogeochemistry of the Waquoit Bay coastal aquifer/subterranean estuary. The first paper addressed the biogeochemistry of Fe, Mn, P, Ba, U, and Th from the perspective of the sediment composition of cores. (Charette et al., 2005). By focusing on this group of elements, four important classes of reactions (and reactants) are studied. These include [1] redox-controlled solubility (Fe, Mn and U), [2] adsorption ( $\mathrm{P}, \mathrm{Th}, \mathrm{Ba}, \mathrm{Ra})$ onto the oxides of $\mathrm{Fe}$ and $\mathrm{Mn}$, [3] release $(\mathrm{P}, \mathrm{Ba}, \mathrm{Ra})$ from oxides undergoing reductive dissolution, and $[4]$ desorption $(\mathrm{Ba}, \mathrm{Ra})$ from sediments via ion-exchange reactions. This paper will use ground (or pore) water and Bay surface water data to establish a more detailed view into the estuarine chemistry and the chemical diagenesis of $\mathrm{Fe}, \mathrm{Mn}, \mathrm{U}, \mathrm{Ba}$ and $\mathrm{Sr}$ in the coastal aquifer. The small and confined nature of the subterranean estuary in Waquoit Bay allows these two papers to provide an in-depth study of the major biogeochemical reactions operating on the permeable sediments of a coastal aquifer with active Fe and $\mathrm{Mn}$ redox cycles and well-defined salinity gradients.

"Groundwater" and "pore water" are terms which refer to water within sediments. The term groundwater is usually associated with freshwater systems and has the connotation of flow. Pore water is extensively used in papers on marine systems. These terms will be used interchangeably in this paper on subterranean estuaries.

\section{EXPERIMENTAL METHODS AND PROCEDURES}

\subsection{Field Methods}

A series of groundwater (or pore water) profiles were collected from the head of Waquoit Bay during July 2002 (Fig. 1; Table 1). In order to obtain a 2-D representation of the geochemical properties across the aquifer's salinity gradient, we conducted a six station transect perpendicular to the shore line (Fig. 1; line A-A', piezometer stations \# 3, 5, 6, 7, 8 and 10). This transect began at the berm of the beach and extended 17-m to a point several meters below 
the low tide mark. We also sampled at four other stations along a $180 \mathrm{~m}$ transect which ran parallel to the shore (Fig. 1; line B-B'and piezometer stations \# 1, 2, 4 and 9). Each profile required 4 to 8 hours of sampling, and the sampling covered 17 days ( 7 June to 3 July). Hence, the pore water data do not represent synchronous distributions of the measured parameters.

The groundwater samples were obtained with a stainless steel drive point piezometer system ("Retract-A-Tip" from AMS, Inc. Idaho, USA). Water samples were collected at $\sim 0.5 \mathrm{~m}$ intervals in the fresh and saline portions of the aquifer and at $0.15 \mathrm{~m}$ intervals when the salinity gradient was encountered. Groundwater samples were brought to the surface through acidcleaned Teflon or polypropylene tubing using a peristaltic pump at a flow rate of $10-50 \mathrm{ml} \mathrm{min}^{-1}$. After a minimum 3-fold flushing the tubing volume and stabilization of salinity, $\mathrm{pH}$ and dissolved $\mathrm{O}_{2}$ readings, samples for trace metal analysis were directly filtered into acid cleaned 15 $\mathrm{ml}$ LDPE bottles using an all-plastic syringe and a $0.2 \mu \mathrm{m}$ (pore sized) capsule filter. Each sample bottle was preloaded with $20 \mu \mathrm{L}$ of trace metal grade nitric acid $(8 \mathrm{M})$. This technique lead to the immediate acidification of each filtered sample to $\mathrm{pH} 1-2$.

We used a YSI 600R multi-probe (Salinity, Temperature, DO, pH) with a flow through cell (YSI, Inc.) to guide our sample collection strategy in the field. In addition, separate discrete water samples were collected for salinity (Guideline AutoSal) and dissolved oxygen (Winkler titration) determinations which were conducted back in the laboratory. A separate filtered sample was also collected and stored frozen for nutrient analysis. Nutrients $\left(\mathrm{NO}_{3}{ }^{-} / \mathrm{NO}_{2}{ }^{-}, \mathrm{PO}_{4}{ }^{3-}, \mathrm{NH}_{4}{ }^{+}\right.$, $\mathrm{SiO}_{4}{ }^{-}$) were analyzed via a flow injection colorimetric method (Lachat QuickChem 8000) and will be discussed in separate manuscript.

Surface water samples were collected from Waquoit Bay during a July 1999 cruise described in Charette et al. (2001), which focused on Ra as a tracer of SGD into the Bay. We analyzed these archived samples, which were collected with a peristaltic pump and syringe filtered $(<0.2 \mu \mathrm{m})$ into acid cleaned LDPE bottles, for dissolved $U$ and Ba concentrations (Table 2). 


\subsection{Laboratory Methods and Analysis}

The ground (pore) water and surface Bay water concentrations of total dissolved Fe, $\mathrm{Mn}$, $\mathrm{Ba}, \mathrm{Sr}$ and $\mathrm{U}$ were measured by inductively coupled plasma mass spectrometry (ICP-MS) as described in Charette et al. (2005). Briefly, each sample was diluted 1:20 with $1 \mathrm{~N}$ nitric acid. Standards were prepared in the same acid. Indium (In), added to samples and standards, served as an internal standard in order to quantitatively account for variations in the performance of the mass spectrometer during analysis. The resulting In count rate data was used to normalize the mass spectrometer count rate for Fe, Mn, Ba, Sr and U. A Finnigan Element High Resolution ICP-MS, operated by the WHOI Mass Spectrometry facility, was used in low-resolution mode for In (115), U (238), and $\mathrm{Ba}$ (137) and in the medium-resolution mode for $\mathrm{Mn}$ (55), Fe (56), and In (115). Given the high precision and accuracy requirements for the surface water $U$ determination, these samples were analyzed via isotope dilution ICP-MS using ${ }^{232} \mathrm{U}$ as the spike. The analytical methods associated with the sediment compositions are described in Charette et al. (2005).

\section{RESULTS and DISCUSSION}

The elemental concentrations of the pore water profiles and surface Bay water are contained in tables 1 and 2 respectively. While this paper will only discuss salinity, $\mathrm{Fe}, \mathrm{Mn}, \mathrm{Ba}$, $\mathrm{Sr}$ and $\mathrm{U}$, these tables also contain data for dissolved oxygen, dissolved organic carbon, $\mathrm{PO}_{4}{ }^{3-}$, and $\mathrm{SiO}_{4}{ }^{-}$. Figures 2 and 3 provide two-dimensional distributions of salinity, $\mathrm{Fe}, \mathrm{Mn}, \mathrm{Ba}$ and $\mathrm{U}$. These 2-D plots are derived from the transect perpendicular to the shore line (Fig. 1; line A-A', piezometer stations \# 3, 5, 6, 7, 8 and 10). The vertical profiles in figure 4 illustrate the major downward variations in the pore water concentrations of Fe, $\mathrm{Mn}, \mathrm{Ba}$, and $\mathrm{U}$ from stations PZ7 and PZ3. PZ7 is almost entirely in the freshwater region of the SGD while PZ3 captures the full salinity gradient of the subterranean estuary. Sr data are only available for PZ3.

Figures 5, 6 and 7 compare and contrast the salinity-based distribution of $\mathrm{Ba}, \mathrm{Sr}$ and $\mathrm{U}$ in the pore water and Bay water samples. Figure 5 and 6 compare the Ba-salinity and Sr-salinity distributions of the pore water and Bay water samples. Figure 7 compares the U-salinity 
distributions of the pore water and Bay water samples. It also shows the predicted U-salinity distribution based on conservative mixing between open ocean seawater and the aquifer's freshwater end-member.

We have used Ba-salinity and U-salinity distributions of the surface Bay water in figures 5 and 7 to extrapolate to their zero salinity concentrations. This approach was used by Boyle et al. (1974) as means of estimating the extent to which an element is released to or removed from the mixing zone of estuaries. This type of extrapolation yields what is called the "effective zero salinity end-member concentration”. Coffey et al. (1997) have employed this approach to Ba data from many estuaries. As the salinity range of our Bay water samples is narrow (27.5 to 31.5), our extrapolations for Ba and U carry large uncertainties. As noted later, the extrapolated concentrations of $\mathrm{Ba}$ and $\mathrm{U}$ are consistent with other evidence for their addition and removal within the subterranean estuary.

Figure 8 plots dissolved $\mathrm{Mn}$ against dissolved $\mathrm{Ba}$ for pore water samples collected in the middle of A-A' transect of the subterranean estuary at PZ3, PZ6 and PZ8. Finally, because the B-B' transect only includes 4 stations spanning $200 \mathrm{~m}$ versus 6 stations across $17 \mathrm{~m}$ for the AA' transect, we do not include contour plots for these sites. However, the data are presented in Table 1 and discussed throughout the paper.

\subsection{Salinity Distribution in the Bay and its Subterranean Estuary}

Background into the hydrological and geological setting of the study site has been presented in Charette et al. (2005). A brief overview follows. As shown in Figure 1, Waquoit Bay is a shallow, semi-enclosed and tidally-flushed estuary located on the south shoreline of Cape Cod (MA, U.S.A.). The upper $\sim 10 \mathrm{~m}$ of the Cape Cod Aquifer consists of a relatively homogeneous distribution of highly permeable sediment along the shoreline of Waquoit Bay (Cambareri and Eichner, 1998). Because the soil on Cape Cod is primarily composed of coarsegrained sand, precipitation tends to infiltrate the sediments rather than become surface runoff. Thus, groundwater is the major source of freshwater to the Bay and to the two small rivers that 
drain into it (Cambareri and Eichner, 1998; Valiela et al., 1990; Charette et al., 2001; U.S. Geological Survey, 2003).

Unlike the piezometer-collected pore water samples, which cover the whole mixing zone (Fig. 2), the salinity of our surface Bay waters only covers a small range (27.6 to 31.5) (Figs. 57). Surface water salinity generally increases with distance from the head to the mouth of the bay (Charette et al., 2001). For example, the salinity near the head of the Bay is 27.61 and increases to 31.49 in Vineyard Sound outside the inlet to the Bay. This salinity pattern supports the idea that the head of the bay, the location of our piezometer survey, is an important source of SGD to the system (Charette et al., 2001).

The 2-D distribution of pore water salinity in figure 2 a shows that there is a well-defined subterranean estuary beneath the head of the Bay. The main feature is a narrow seepage face where zero salinity groundwater flows upward to the surface of the beach. Seepage meter studies of the intertidal zone confirm that submarine (saline) groundwater discharge also occurs in a narrow ( $\sim 25 \mathrm{~m}$ wide) band along the head of the bay (Michael et al., 2003; Sholkovitz et al. 2003). As Figure 2a reveals, sharp salinity gradients exist over short distances in both the vertical and horizontal directions. For example, salinity increases from 0 to 28 over 2.5 vertical meters in the center of the beach. This same large salinity gradient occurs over a horizontal distance of less than $10 \mathrm{~m}$ in the upper meter of beach sediments. These large salinity gradients result in a strong pycnocline, which leads to vertical and horizontal density stratification within the subterranean estuary.

The salinity distribution along the B-B' shore parallel transect (PZ 1-4; Table 1) also shows that there is a sharp boundary between fresh and saline groundwater. The upper sections of profiles from PZ 1, 2 and 4 also show a reverse salinity gradient, a transient features which results from tidally pumped seawater into the upper $\sim 1 \mathrm{~m}$ of the sediment column during high tides. 


\subsection{REDOX Framework of the Subterranean Estuary: Fe and Mn}

This section sets the REDOX (oxidation-reduction) framework of the subterranean estuary, which is described in more detail in both Charette and Sholkovitz (2002) and Charette et al. (2005). The 2-D distributions of pore water Fe and Mn along transect A-A' and the vertical profiles from PZ7 and PZ3 (Figs. 2 and 4) show that the subterranean estuary in Waquoit Bay has two distinct sources of the high concentrations of total dissolved and reduced Fe and Mn. One source resides in the upward rising plume of freshwater, and the second source lies in the salt-wedge zone of mid to high salinity pore water. The distribution of $\mathrm{Fe}$ and $\mathrm{Mn}$ within the freshwater region of the subterranean estuary shows that there is a plume of Fe and $\mathrm{Mn}$ rich groundwater moving toward the Bay (Figs. 2 and 4). This plume is centered between a depth of 2 and $4 \mathrm{~m}$ and carries up to $175 \mu \mathrm{M}$ of Fe and $15 \mu \mathrm{M}$ of $\mathrm{Mn}$. As the leading edge of this plume moves upward toward the beach, almost all of the Fe and Mn are removed over horizontal and vertical distances of only a few meters. (Our measurements of ferrous and total dissolved iron concentrations by the ferrozine colorimetric method of Stookey (1970) show that the major fraction of the total dissolved Fe in this subterranean estuary was in the reduced or ferrous form).

The second source of dissolved Fe and Mn lies in the salt wedge section of the subterranean estuary where pore water concentrations reach $50 \mu \mathrm{M}$ of Fe and $40 \mu \mathrm{M}$ of $\mathrm{Mn}$ (Figs. 2 and 4). These high concentrations of $\mathrm{Fe}$ and $\mathrm{Mn}$ are associated with a pore water salinity that exceeds 5-10. Another key redox feature in the salt-wedge section of the subterranean estuary is the fact that a lens of high Mn concentration lies over a lens of high Fe concentration (Figs. 2 and 4)

Unlike the A-A' transect, the stations from the shore parallel (B-B') transect were too far seaward to capture the Fe and Mn plumes of the zero salinity groundwater. However, the B-B' distribution of $\mathrm{Fe}$ and $\mathrm{Mn}$ in the salt-wedge section of the subterranean estuary were similar to the A-A' transect in that the Mn concentration peaks were generally above the Fe concentration maxima. The concentration ranges were much higher than those of the A-A' transect. Mn approaches $100 \mu \mathrm{M}$ at a depth of $\sim 2 \mathrm{~m}$ in PZ1 and Fe reaches a peak of nearly $500 \mu \mathrm{M}$ at $\sim 8 \mathrm{~m}$ in PZ4. 
Charette and Sholkovitz (2002) collected $\sim 2 \mathrm{~m}$ long sediment cores from the fully saline and intertidal section of the subterranean estuary at the head of Waquoit Bay (near PZ8 in Fig. 1). The most outstanding visual features of these cores are their colors. Charette and Sholkovitz (2002) showed that the dark red, yellow and orange colors of the Waquoit Bay cores were iron (hydr)oxide precipitates loosely bound to sand grains. The deeper sections of the cores are characterized by large amounts of iron (hydr)oxides (ferrihydrite, lepidocrocite and goethite) that are being precipitated onto organic C-poor quartz sand (Charette et al. 2005). Unlike Fe (hydr)oxides which increase with depth, the Mn (hydr)oxides display well-developed maxima in the mid-sections of cores 2 and 3. This type of vertical stratification is consistent with redoxcontrolled diagenesis in which Mn (hydr)oxides are formed at shallower depths than iron (hydr)oxides. The reduction of seawater-derived sulfate and the production of sulfides are not important parts of the redox-driven cycles in this system. As noted later in the context of their pore water gradients, the sediment profiles are also characterized by enrichments in $\mathrm{Ba}$ and $\mathrm{U}$.

In summary of this section, all of the observations point to active Fe and Mn redox cycles in this coastal aquifer, even though the concentration of solid-phase organic carbon in the Waquoit Bay sediments is low $(<0.1 \%$; Charette et al., 2005). Groundwater from the land delivers high concentrations of dissolved ferrous iron and reduced manganese to the freshwater end of the subterranean estuary where a large fraction of this dissolved $\mathrm{Fe}$ and $\mathrm{Mn}$ is oxidized and precipitated onto the quartz beach sands. There is also production, transport and subsequent oxidation of reduced $\mathrm{Fe}$ and $\mathrm{Mn}$ at the high salinity end of the subterranean estuary where the formation of iron (hydr)oxide rich sands are forming (Charette and Sholkovitz, 2002; Charette et al., 2005).

\subsection{Barium in the Subterranean Estuary and the Bay}

A major feature of this study is the large-scale enrichment of $\mathrm{Ba}$ in the subterranean estuary of Waquoit Bay with respect to the concentrations of $\mathrm{Ba}$ in both the freshwater and seawater end-members (Figs. 3-5). Barium concentrations span nearly four orders of magnitude from $\sim 1 \mathrm{nM}$ to $2800 \mathrm{nM}$ (Figs. 3-5). Coastal seawater in Vineyard Sound contains $\sim 25 \mathrm{nM}$ of dissolved $\mathrm{Ba}$; the freshwater portion of the aquifer is also characterized by low $\mathrm{Ba}$ concentration (10-50 nM). As shown in the 2-D distributions of the shore-perpendicular transect (Fig. 3), Ba 
reaches high concentrations at the upper side of the salinity transition zone (STZ). This feature is most pronounced in PZ3 where Ba concentrations increase from $66 \mathrm{nM}$ at a depth of $1.52 \mathrm{~m}$ and a salinity of 0.46 to a value of $1227 \mathrm{nM}$ at a depth of $2.29 \mathrm{~m}$ and a salinity of 15.1 . The concentration of $\mathrm{Ba}$ decreases with increasing depth and salinity. Hence, Ba exhibits a subsurface maximum that spans $\sim 1.5 \mathrm{~m}$ and lies between the zones of fresh and saline pore water.

The Ba-salinity distribution for all the pore water samples confirms that $\mathrm{Ba}$ follows a strongly non-conservative mixing distribution (Fig. 5a). Again, the Ba concentration is highest in the STZ and generally decreases from mid salinity $(\sim 20)$ to high salinity. The low Ba values in a handful of STZ samples are associated with shallow samples from the piezometer profiles, and are, therefore, an indicator of recent seawater infiltration. In B-B' transect along the shoreline there is a clear trend of decreasing Ba from west (PZ1) to east (PZ4) (Table 1). Maximum Ba concentrations decreased from 2800 to $260 \mathrm{nM}$.

Given the scatter when plotting all of the pore water Ba against salinity (Fig. 5a), it is difficult to estimate the "effective" zero-salinity concentration within the subterranean estuary. We have done so using the Ba-concentration diagram for PZ3 only (Fig. 5a). When one extrapolates from the high salinity zone back to zero salinity, the "effective" Ba concentration is $\sim 2700 \mathrm{nM}$. In context, the measured Ba concentration of the fresh ground water entering the subterranean estuary is 10-50 nM, or two orders of magnitude lower (Fig. 3).

As shown in Figures 2-4, a prominent feature of our pore water data set is that the subsurface maximum in Ba coincides with a lens of elevated Mn concentrations. The lens of high $\mathrm{Ba}$ and $\mathrm{Mn}$ are both associated with the STZ. In contrast, the lens of high dissolved Fe concentration lies much deeper in the salt wedge region of the subterranean estuary. As will be discussed later, our data suggest that the redox geochemistry of $\mathrm{Mn}$ (and not $\mathrm{Fe}$ ) has an important controlling role in forming the elevated concentrations of $\mathrm{Ba}$.

Within the surface Bay water samples, Ba concentrations increase with decreasing salinity (Fig. 5b). Barium in the high salinity waters of Vineyard Sound is $\sim 25 \mathrm{nM}$ and increases 
to $55-75 \mathrm{nM}$ at the lowest salinity (27.6-28.0) samples near the head of the Bay. Though the Ba pattern within the Bay are somewhat scattered, highest values were generally associated with stations at the head of the Bay. If one extrapolates the Ba concentration back to zero salinity, then the "effective" Ba concentration is approximately $250 \mathrm{nM}$ (Fig. 5b). Hence, the "effective" freshwater end-member concentration of $\mathrm{Ba}$ for the surface samples is 5-25 times higher than the $\mathrm{Ba}$ concentration of the ground water and sea water flowing into the subterranean estuary. The "effective" Ba concentration for the pore water samples of PZ3 (Fig 5a; $2700 \mathrm{nM}$ ) is 11 times higher than its counterpart for the Bay's surface waters $(250 \mathrm{nM})$

\subsection{Strontium in Subterranean Estuary and the Bay}

Strontium was not part of our initial suite of trace metals analyzed. To date we have only analyzed samples from PZ3 (Figs. 4 and 6). Groundwater concentrations ranged from $0.2 \mu \mathrm{M}$ at a salinity of $\sim 0$ to $84 \mu \mathrm{M}$ at a salinity of 27 . Strontium was only measured on three surface samples from the Bay where the Sr concentrations range from 68-76 $\mu \mathrm{M}$ and are positively correlated with salinity. The three samples fall along a mixing line between the fresh groundwater end-member and the mean ocean water concentration of Sr (Pilson, 1998). Hence, the Sr-salinity distribution indicate that $\mathrm{Sr}$ is conservative within the Bay itself, albeit with only three samples as evidence.

The Sr-salinity distribution in figure 6 shows that dissolved Sr behaves nonconservatively within the subterranean estuary. The extent to which $\mathrm{Sr}$ is released to the subterranean estuary depends on the choice of the high salinity end-member. If we use the linear mixing line between local coastal sea water, Bay surface water and zero salinity groundwater in Figure 6 as the conservative distribution, then the Sr-salinity distribution suggests a $26 \%$ elevation in the amount of Sr added to the subterranean estuary. This value was calculated by measuring the area under pore water Sr-salinity distribution relative to the area under the conservative mixing line in Figure 6.

We have also estimated the "effective zero-salinity Sr concentration" of pore water samples from PZ3 by extrapolating the high salinity distributions back to zero salinity (Fig. 6). This yields an effective end-member concentration of $\sim 20 \mu \mathrm{M}$. Unlike $\mathrm{Ba}$, the effective 
concentration of $\mathrm{Sr}$ is much less than its seawater end-member concentration $(\sim 80 \mathrm{nM})$. But it is significantly higher than the measured fresh water end-member $(\sim 0.1 \mathrm{nM})$.

\subsection{Uranium in the Bay and Subterranean Estuary}

Another major feature of this study is that $\mathrm{U}$ is strongly non-conservative in this subterranean estuary with large-scale removal over the entire salinity range, and some evidence for $U$ release at high salinity end (Fig. 7a). The sea water concentration outside the Bay is $\sim 12$ $\mathrm{nM}$, and the $\mathrm{U}$ in the freshwater plume ranges from below detection to $2.6 \mathrm{nM}$. It is clear from the U-salinity distribution that the removal of sea water- derived U in STZ of the subterranean estuary is nearly quantitative.

The pore water concentration of $U$ in subterranean estuary ranges from below detection to $\sim 20 \mathrm{nM}$ (Figs. 3, 4 and 7). The range in U concentrations for the STZ is similarly low. The high salinity groundwater in the salt-wedge range from detection limit to $\sim 20 \mathrm{nM}$; the majority of the high $U$ values are located in a narrow (25-26) salinity range. Above this salinity, the $U$ concentration range was much smaller $(\sim 0-4 \mathrm{nM})$. Most of the elevated $U$ in the subterranean estuary are located in the high salinity samples from the middle piezometers (PZ6, PZ3) of the shore-perpendicular transect (Figs. 3 and 4).

Uranium concentrations of the Bay's surface water lie within a narrow range $(9.7-12.2$ $\mathrm{nM}$ ) and are positively correlated with salinity (Fig. $\left.7 \mathrm{a} ; \mathrm{R}^{2}=0.80\right)$. However, the U-salinity distributions fall below that of the mixing line that connects the coastal sea water of Vineyard Sound to the zero-salinity groundwater entering the Bay (Fig. 7b). Extrapolation to zero salinity yields an "effective" $U$ concentration of $-5 \mathrm{nM}$, which implies that $U$ is being removed from the Bay's surface water. It appears that our finding of U-depleted surface waters supports our hypothesis of large scale U removal within the subterranean estuary.

\section{BIOGEOCHEMICAL PROCESSES IN THE SUBTERRANEAN ESTUARY}

\subsection{Barium}


This study provides further evidence that biogeochemical reactions can lead to the largescale enrichment of $\mathrm{Ba}$ in subterranean estuaries. To the best of our knowledge, Shaw et al. (1998) and Windom and Niencheski (2003) provide the only other known Ba data across salinity gradients in coastal aquifers. In both cases, groundwater Ba peaked at $2000 \mathrm{nM}$ though at different salinity: 12 (Windom and Niencheski, 2003) or $\sim 20$ (Shaw et al., 1998). These sets of observations are consistent with recent studies suggesting that groundwater is a major source of Ba to the surface waters of estuaries and the coastal ocean (Moore, 1997; Duncan and Shaw, 2003). What processes control Ba cycling in subterranean estuaries, and hence the flux of $\mathrm{Ba}$ to the ocean via SGD? In this section we discuss the following possibilities: (1) ion exchange reactions with seawater, and (2) the redox cycle of $\mathrm{Mn}$, and (3) weathering of Ba-bearing minerals. We will begin with a brief overview of and comparison with "surface estuaries" where rivers are the primary source of fresh water.

The non-conservative behavior of dissolved $\mathrm{Ba}$ is a universal and long-established feature of surface estuaries. Ion exchange, whereby seawater cations substitute for $\mathrm{Ba}$ on the surface of river-borne suspended minerals, has long been identified as the most important mechanism for the release of Ba to surface estuaries. Coffey et al. (1997) summarize the behavior of Ba in a wide range of surface estuaries. Large river estuarine systems are often characterized by broad Ba maxima in the low (0-6) salinity region. In contrast, estuaries of small rivers tend to have their Ba concentration maxima at a higher salinity range (10-15). Coffey et al. (1997) argue that the transit time of Ba-releasing particles through an estuary will be the major factor in controlling the salinity region over which a $\mathrm{Ba}$ maxima is developed. Coffey et al. also note that the desorption of $\mathrm{Ba}$ off river suspended matter occurs on the time scale of minutes to hours at low salinity $(>\sim 2)$. The non-conservative distribution of $\mathrm{Ba}$ in surface estuaries has been successfully modeled by invoking ion-exchange reactions between sea water and fresh river particles (Hanor and Chan, 1979).

The principal source of dissolved Ba to the mixing zone of a surface estuary is the delivery of river suspended particles (Coffey et. al., 1997). This leads to a continual source of "new" Ba that can be released from fresh river particles at low to intermediate salinities. While some new fine-grained particles may be transported by ground water and recirculating sea water, 
subterranean estuaries like Waquoit Bay are not supplied with a continual source of fresh mineral particles. The bulk of the sediments in most coastal aquifers are stationary, "old" and more coarse-grained than the suspended particles that characterize rivers and surface estuaries.

When the data for all the pore water samples are used in a Ba-salinity scatter diagram (Fig. 5), one feature of note is that the maximum in the concentration of $\mathrm{Ba}$ is skewed toward the higher (15-25) end of the salinity gradient (Fig. 5). Hence, the addition of dissolved Ba to this subterranean estuary appears to occur at salinities which are higher than those associated with most surface estuaries (Li and Chan, 1979; Coffey et al., 1997). The Ba-salinity distribution for PZ3 profile is the only exception to this observation as the peak in $\mathrm{Ba}$ is centered on a salinity of 15; its overall distribution is similar to many surface estuaries (Fig. 5a). Thus, the mechanisms driving Ba enrichment in surface estuaries cannot completely account for the Ba excess observed in all subterranean estuaries, except in the case of constant landward intrusion of seawater into coastal aquifers (Moore, 1996).

While $\mathrm{Ba}$ and the other alkaline earth elements ( $\mathrm{Sr}, \mathrm{Ra})$ do not have a redox chemistry of their own, we argue that the elevated Ba concentrations in the pore water of Waquoit Bay are caused in part by the reduction and oxidation cycles of Mn. It is well known that Ba (and Ra) has an exceptionally strong affinity for Mn (hydr)oxides (Balistrieri and Murray, 1986; Sugiyama et. al., 1992; Mishra and Tiwary, 1993). In fact, $\mathrm{MnO}_{2}$ impregnated acrylic fibers are used to quantitatively extract Ra from seawater (Moore and Reid, 1976). We suggest a process that is very similar to the coupled redox cycle of Mn and Ba that De Lange et al. (1990) applied to the interface between oxic seawater and anoxic brine water in Bannock basin. Their basic idea is that $\mathrm{Ba}$ is recycled at the oxic/anoxic boundary where high concentrations of $\mathrm{Ba}$ are maintained as part of the redox cycle of $\mathrm{Mn}$. In this scenario, $\mathrm{Ba}$ is adsorbed onto $\mathrm{Mn}$ oxides formed from the oxidation of dissolved $\mathrm{Mn}$ (II) and released back to the deeper water column as reducing conditions dissolve the Mn oxides. Our field evidence for both the pore water and sediments (Charette et al., 2005) support a coupled redox and salt cycle for Ba. Indeed, the 2-D distributions across transect A-A' and the vertical profiles in PZ3 show that the lens of high pore water $\mathrm{Ba}$ is coincident with both a lens of high dissolved Mn (Figs. 2-4) and a strong gradient in 
salinity. Mn-Ba concentration plots show a strong inter-element correlation for pore water samples; this is not the case for Fe-Ba plots (Fig. 8).

How can this Mn-redox driven cycle of Ba operate in a system that is dominated by the Fe-redox cycle? The answer lies in the fact that the affinity of $\mathrm{Ba}$ for $\mathrm{Mn}$ oxides is several orders of magnitude greater than the affinity of Ba for Fe oxides (Balistrieri and Murray, 1986; Sugiyama et al., 1992; Mishra and Tiwary, 1993; Tonkin et al., 2004). This difference is consistent with the fact that the lens of high pore water $\mathrm{Ba}$ in subterranean estuary lies coincident with a lens of Mn but not Fe (Figs. 2-4). The redox cycle of Fe leads to the production of dissolved Fe at a depth underlying that of $\mathrm{Mn}$ and $\mathrm{Ba}$.

The Ba-Mn dynamics in the subterranean estuary of Waquoit Bay are likely to be reversible under certain conditions. That is, dissolved Ba will most likely be co-precipitated upon the oxidation of dissolved Mn to Mn (hydr)oxides. Thus, it is possible that there is $\mathrm{Ba}$ removal at the low to mid salinities that would otherwise be characterized as a zone of large $\mathrm{Ba}$ enrichment. Coffey et al. (1997) note that Ba removal occurs in the low salinity zones of several surface estuaries; they suggest removal by oxide formation. In this scenario, a subterranean estuary would be characterized by a coupled $\mathrm{Ba}-\mathrm{Mn}$ co-precipitation cycle in the low salinity region that maintains Ba concentrations at low (but still highly enriched over surface waters) concentrations while the peak at higher salinity is controlled by Mn (hydr)oxide reduction as described above. The profiles in PZ3 point to the removal of dissolved $\mathrm{Ba}$ in association with the removal of dissolved Mn by oxidation to Mn oxides (Fig. 4).

A third factor that could explain the distribution of $\mathrm{Ba}$ in the subterranean estuary is the slow weathering of aquifer solids. In contrast with the surface estuary, which continually receives "new" Ba through the transport of suspended particles, the particles that comprise a subterranean estuary are essentially static, though the potential contribution of mobile colloidal organic and lithogenic phases cannot be discounted (e.g. Ouyang et al., 1996). Thus, in a scenario where the sea level and aquifer recharge is relatively constant (hence, a relatively constant location of the groundwater-seawater mixing zone on decadal time scales), one would expect the desorptive input of $\mathrm{Ba}$ (and other alkaline earth elements) to be minimized. Only 
through the exposure of newly ion exchangeable Ba via slow weathering of aquifer minerals could this non-conservative release of $\mathrm{Ba}$ be maintained. Since silicate has been shown to be a good indicator of mineral weathering in groundwater systems, one piece of evidence in favor of the slow weathering hypothesis is the highly enriched silicate concentrations we observed in the Waquoit Bay subterranean estuary (Table 1). For example, Rogers and Bennett (2004) noted that microorganisms, both directly and indirectly, can lead to the dissolution of silicate bearing minerals in groundwater systems.

Another interesting aspect of the Ba cycle in the Waquoit Bay subterranean estuary is that it is supersaturated with respect to barium sulfate (barite) formation at nearly all depths and locations (Fig. 5). Charette et al. (2005) reported that sulfate concentrations were not depleted to any significant extent in pore water samples from PZ3. Therefore, non-conservative sulfate behavior is not a likely explanation for the high Ba values we observed. This leaves three likely scenarios: 1) the rate of $\mathrm{Ba}$ flux to surface waters exceeds the rate of barite formation in the subterranean estuary, 2) the excess Ba is complexed by DOC, and/or 3) the "dissolved" Ba we are measuring was actually bound to Mn-oxides.

Ba supersaturation has been observed in many other coastal groundwater settings (Shaw et al., 1998; Windom and Niencheski, 2003; Duncan and Shaw, 2003). The relatively fast groundwater flow rates in Waquoit Bay (Cambareri and Eichner, 1998; Charette et al., 2001; Abraham et al., 2003) favor the hypothesis that barite formation kinetics are the major control on Ba concentration in our study. Laboratory experiments of barite precipitation in decaying plankton microenvironments suggest that the process occurs on a time-scale of weeks to several months (Ganeshram et al., 2003), significantly longer than the residence time of groundwater in the subterranean estuary of Waquoit Bay (days to weeks). Conversely, DOC concentrations are sufficiently high $(50-700 \mu \mathrm{M})$ in this setting that Ba-DOC complexation may also play a factor as has been suggested in many studies of REE in aquatic environments (Duncan and Shaw, 2003).

\subsection{Biogeochemistry of $\mathrm{Sr}$ in the Subterranean Estuary}


The sorption affinity of alkaline earth elements to Mn oxides has the following order, $\mathrm{Ra}>>\mathrm{Ba}>>\mathrm{Sr}$ (Balistrieri and Murray, 1986; Sugiyama et al., 1992; Tonkin et al., 2004). Hence, the release and removal of $\mathrm{Sr}$ in conjunction with a Mn-redox cycle is expected to be much less strong than that of $\mathrm{Ba}$. This prediction is consistent with our observation for the subterranean estuary of Waquoit Bay where Sr is much more conservative than Ba (Figs. 4 and 6) The excess inventory of Sr within this subterranean estuary represents, at most, a $26 \%$ elevation over that expected from conservative mixing (Fig. 6). Studies of seasonally anoxic lakes also show that Ba is much more biogeochemically reactive than Sr (Sholkovitz, 1985; McGrath et al., 1989). Anoxic freshwaters have elevated concentrations of Ba but not Sr.

In a study of $\mathrm{Sr}$ and $\mathrm{Sr}$ isotopes in the Ganges-Brahamaputra (G-B) delta, Basu et al. (2001) concluded that "subsurface flowing groundwater's ... is a potential source of strontium to the oceans, equal in magnitude to the dissolved strontium concentrations carried to the oceans by the G-B river water" and have "...an enormous effect on interpreting the seawater $\mathrm{Sr}$ isotope balance." However, these investigators looked only at $\mathrm{Sr}$ in the freshwater portion of the aquifer and did not take into account the potential for $\mathrm{Sr}$ and $\mathrm{Sr}$ isotopes to be modified during transit through the subterranean estuary. Our Sr results indicate that submarine groundwater discharge could be even more important in controlling the marine Sr budget than Basu et al. (2001) realized.

In their estimate of the global flux of Sr due to SGD, they used a groundwater end member of $\sim 7 \mu \mathrm{M}$. Our data indicate that this value could be much higher ( $20 \mu \mathrm{M}$; Fig. 8) if Sr proves to be non-conservative in other coastal aquifers. This result has significant implications for the $\mathrm{Sr}$ isotopic record on geologic time-scales. In a study of Ra isotopes in a coastal salt marsh, Charette et al. (2003) noted that seasonal/interannual changes in the water table elevation of coastal aquifers are a major factor in alkaline earth elemental fluxes to the ocean through SGD. Similarly, salt water intrusion into coastal sediments during periods of sea level rise may have resulted in significantly elevated inputs of elements like $\mathrm{Sr}, \mathrm{Ba}$, and $\mathrm{Ra}$. Indeed, Cochran et al. (2003) invoked the subterranean estuary concept to explain the Sr isotopic record of fossils from the Late Cretaceous Western Interior Seaway. These lines of evidence are supporting SGD as a major, yet unconstrained, non-steady state source of alkaline earth elements to the ocean that 
may be so significant as to change our interpretation of certain paleoproxies that rely on $\mathrm{Ba}$ or $\mathrm{Sr} / \mathrm{Sr}$ isotopes.

\subsection{Geochemistry of Uranium in the Subterranean Estuary}

In contrast with the alkaline earth elements, the Waquoit Bay subterranean estuary is a sink for uranium; our U-salinity distribution shows strong evidence of removal at intermediate salinity and some evidence of $U$ release near bay water salinity (Fig. 7). Uranium is typically conservative in oxic seawater where its oxidation state is +6 and it forms a strong complex with the carbonate ion (Koide and Goldberg, 1963). One exception would be the presence of Fe (hydr)oxides, for which $U$ has a relatively strong affinity, especially in freshwater. Under reducing conditions such as in organic rich sediments or oxygen poor ground water, U(IV) is very particle reactive and therefore reducing environments represent a sink for $U$ (Cowart, 1980; Cochran et al. 1986). Which of these U removal mechanisms is most important in the Waquoit Bay subterranean estuary?

There exist many case studies of uranium displaying both conservative and nonconservative mixing behavior in surface estuaries. Several studies have shown the Amazon River estuary to be a net sink of $U$. Removal processes at low to intermediate salinities include colloidal aggregation, flocculation, and adsorption onto resuspended sediments (e.g. Swarzenski et al., 1995; Swarzenski and McKee, 1999). Swarzenski et al. (2004) observed nearly conservative mixing of $U$ in the Fly River estuary (Paupa New Guinea), though U-isotopes indicated that the element is being actively cycled between the water column and sediments. In contrast, Shaw et al. (1994) found that the U distribution in the Chesapeake Bay estuary varied with the redox state of the water column; uranium is removed to the sediments during summertime anoxia and then released back to the water column during other (oxic) parts of the year. Despite these case studies, Windom et al. (2000) noted that U removal in estuaries is the exception rather than the rule, except in the case where a salt marsh environment is present.

Two studies comparable to ours also indicate significant removal of seawater-derived U in coastal aquifers. Both Windom and Niencheski (2003) and Duncan and Shaw (2003) observed significant $U$ depletion at intermediate salinities, which they attributed to removal under anoxic 
conditions. Charette and Sholkovitz (2002) reported on the formation of "iron curtain" type sediments in the subterranean estuary beneath Waquoit Bay. Subsequent analysis of the U content in the Fe-enriched cores indicates that $\mathrm{U}$ is not enriched in the Fe oxide-forming region but rather in the shallow reducing sections of the cores (Charette et al. 2005). It appears that the presence of Fe (hydr)oxides in large amounts is not important in controlling $\mathrm{U}$ removal in this environment. It is more likely that the reduction of $U(V I)$ to $U(I V)$ is controlling $U$ removal in Waquoit Bay and in other subterranean estuaries (e.g. Windom and Niencheski, 2003).

Seven of our high (20-30) salinity groundwater samples have U concentrations that exceed the predicted concentrations based on the mixing line with Bay water as the high salinity end member (Fig. 7). Though there is no strong correlation between dissolved oxygen and U, we suspect that the high $U$ values are due to the release of adsorbed U(IV) under more oxidizing conditions. Shaw et. al. (1994) observed a seasonal pattern of removal and release in the estuarine waters of Chesapeake Bay. Removal of $U$ to the sediment occurs during the summertime periods of bottom water anoxia; release to the water column from the sediment occurs during oxic conditions. Cochran et al. (1986) found that the exposure of coastal marine sediments to the air led to a release of $U$ in excess of the local seawater concentration. Barnes and Cochran (1990) demonstrated that the return of oxic conditions in the sediments $U$ release was rapid (minutes to hours) and quantitative. Hence, one would expect large-scale release of $U$ in our subterranean estuary upon the return of oxygenated pore water to the mixing zone.

The large-scale U removal observed in the subterranean estuary is reflected in the Usalinity distribution of the surface water of Waquoit Bay (Fig. 7). We believe that this is the first water column evidence of $U$ removal in the coastal ocean that can be attributed to SGD. It should be noted that the water column samples were collected in 1999, three years earlier than our groundwater samples. Thus, our conclusion that the surface water data reflect a subsurface removal process is based on the assumption that the removal is stable over time. Whereas samples from outside the bay followed the U-salinity relationship of Chen et al. (1986), all samples within the bay fell below the line. Extrapolating the Waquoit Bay $U$ trend back to the zero salinity intercept yields an effective groundwater end member of about $-5 \mathrm{nM}$, or about a $50 \%$ removal efficiency on average (Fig. 7). Using a Waquoit Bay SGD flux of $30 \mathrm{~m} \mathrm{y}^{-1}$ as 
determined by Abraham et al. (2003), we estimate that our subterranean estuary removes 150 $\mu \mathrm{mol} \mathrm{U} \mathrm{m} \mathrm{y}^{-2} \mathrm{y}^{-1}$ (Table 3). Our estimate is slightly higher than that of Duncan and Shaw (2003) who estimated an SGD-derived removal flux of 30-60 $\mu \mathrm{mol} \mathrm{U} \mathrm{m}{ }^{-2} \mathrm{y}^{-1}$. In contrast, Windom et al. (2000) estimated that salt marshes remove $70 \mu \mathrm{mol} \mathrm{U} \mathrm{m} \mathrm{y}^{-2}$ and Cochran (1982) reported the marine sediments flux to be $0.4 \mu \mathrm{mol} \mathrm{U} \mathrm{m} \mathrm{m}^{-2}$.

How important might SGD-derived removal of $\mathrm{U}$ be on a global basis? With global estimates of SGD ranging from 4,000 to $100,000 \mathrm{~km}^{3} \mathrm{y}^{-1}$ (Burnett et al. 2003), and a groundwater end member as observed for the Waquoit Bay system of $-5 \mathrm{nM}, \mathrm{U}$ removal in subterranean estuaries could range anywhere from 20-500 x $10^{6} \mathrm{~mol} \mathrm{U} \mathrm{y}^{-1}$ (Table 3). Clearly, given that total oceanic $\mathrm{U}$ inputs are not likely much greater than $60 \times 10^{6} \mathrm{~mol} \mathrm{U} \mathrm{y}^{-1}$, our upperlimit estimate is unrealistic. However, such a removal flux would put our lower-limit SGDderived $\mathrm{U}$ sink on par with the global $\mathrm{U}$ sink for marine sediments and salt marshes (both $\sim 27 \mathrm{x}$ $\left.10^{6} \mathrm{~mol} \mathrm{U} \mathrm{y}^{-1}\right)$. We also recognize that not all groundwater circulation may result in $\mathrm{U}$ depletion, and that more refined estimates of $\mathrm{U}$ removal due to SGD will have to consider the location (e.g. coastal hydrogeologic regime) and mechanism of exchange. However, these results are in contrast to the recent work of Dunk et al. (2002), who invoke SGD as a net source of $U$ to the oceans $\left(9.7 \times 10^{6} \mathrm{~mol} \mathrm{U} \mathrm{y}^{-1}\right)$ to achieve a balance for the marine $\mathrm{U}$ budget. Even if some coastal aquifer systems are a net source of $U$ to the oceans (e.g. in Karst-type aquifers), this flux is likely offset or even exceeded by removal of $U$ via seawater circulation through coastal permeable sediments as described here.

\section{CONCLUSIONS}

This study provides solid evidence that biogeochemical reactions can lead to the largescale enrichment of $\mathrm{Ba}$ and depletion of $\mathrm{U}$ in subterranean estuaries. This observation is consistent with recent studies suggesting that groundwater is a major source of Ba to estuaries and the coastal ocean (Moore, 1997; Shaw et al., 1998). In addition, the surface water distributions of $\mathrm{Ba}$ and $\mathrm{U}$ in Waquoit Bay reflect the input and loss processes operating in the subterranean estuary. 
A comparison of $\mathrm{Ba}$ and $\mathrm{Sr}$ distribution in both the pore water and surface waters of Waquoit Bay shows that these two alkaline earth elements differ greatly in their salinity-based distributions and the extent of their estuarine geochemistry. While both elements are released to the pore water of the subterranean estuary, the extent of release is much greater for $\mathrm{Ba}$ than $\mathrm{Sr}$. Ion exchange, whereby sea water cations substitute for $\mathrm{Ba}$ on the surface of river-borne suspended minerals, has long been identified as the most important mechanism for the release of $\mathrm{Ba}$ to surface estuaries. Here, we argue that, in addition to salinity effects, the cycling of $\mathrm{Ba}$ in subterranean estuaries is caused at least in part by the redox cycles of $\mathrm{Mn}$. The sorption affinity of alkaline earth elements to Mn oxides has the following order, $\mathrm{Ra}>>\mathrm{Ba}>>\mathrm{Sr}$. Hence, the release and removal of $\mathrm{Ba}$, in conjunction with a Mn-redox cycle, is expected to be much stronger than that of Sr. This prediction is consistent with our observation for the subterranean estuary of Waquoit Bay where Sr is much more conservative than Ba. In this context, one would predict that the subterranean estuarine geochemistry of Ra, a commonly applied tracer of SGD, would be more Ba-like than Sr-like.

The redox-driven removal of $U$ in the subterranean estuary is reflected in the surface water U-salinity distribution of Waquoit Bay. We believe that this is the first evidence of $U$ removal in the coastal ocean that can be attributed to SGD. Whereas samples from outside the bay followed the U-salinity relationship of Chen et al. (1986), all samples within the bay fell below the line. If the removal of $U$ in our coastal aquifer is scaled to the global estimates of SGD, then our lower-limit of SGD-derived U sink is on par with estimates of the global U sink for marine sediments and salt marshes. These results are in contrast to the recent work of Dunk et al. (2002), who invoke SGD as a net source of $U$ to the oceans to achieve a balance for the marine $\mathrm{U}$ budget.

It remains to be seen if the extent of the observed elemental source/sink mechanisms discussed here are persistent year round and consistent from year to year. For example, seasonal/interannual changes in the water table elevation of coastal aquifers may be a major factor in alkaline earth elemental fluxes to the ocean through submarine groundwater discharge. Similarly, salt water intrusion into coastal sediments during periods of sea level rise may have resulted in significantly elevated inputs of these elements. This could have serious implications 
for the interpretation of marine paleoproxies such as Sr isotopes (e.g. Cochran et al. 2003). Our Sr results indicate that submarine groundwater discharge could be even more important in controlling the marine Sr budget than Basu et al. (2001) realized. Hence, both present day and long (geologic) time-scale budgets for these and other elements with similar chemical properties (e.g. Mo, Re) must consider the submarine groundwater discharge-associated processes discussed here.

Because of the magnitude and range of advective flow and exchange in coastal aquifers, chemical gradients alone are not sufficient predictors of flux to the overlying water column. Thus, a key component of future research into the subterranean estuary would be a combined geochemical and hydrological flow model. Such a model would improve the applicability of our results to other settings by allowing for the evaluation of new hypotheses based on more complex groundwater-seawater mixing zones.

Acknowledgements - We thank Matt Allen, Jeremy Testa, Craig Herbold, Meagan Gonneea and Adam Rago for their help in the field and in the laboratory. Lary Ball and David Schneider of the WHOI ICP-MS Facility performed the trace metal analyses. We extend our continued appreciation to the director and staff of the Waquoit Bay National Estuarine Research Reserve for their assistance with logistics during field sampling. Finally, we thank Associate Editor Tim Shaw and two anonymous reviewers for their comments, which greatly improved the manuscript. This research was supported by the National Science Foundation (OCE-0095384) to M.A.C. and E.R.S., and a WHOI Coastal Ocean Institute Fellowship to M.A.C.

\section{REFERENCES}

Abraham, D.R., Charette M .A., Allen M.C., Rago A. and Kroeger, K.D. (2003) Radiochemical estimates of submarine groundwater discharge to Waquoit Bay, Massachusetts. Biol. Bull. 205, 246-247. 
Balistrieri L. S., and Murray J. W. (1986) The surface chemistry of sediments from the Panama Basin: The influence of Mn (hydr)oxides on metal adsorption. Geochim. Cosmochim. Acta 50, 2235-2243.

Barnes, C.E., and Cochran, J.K. (1990) Uranium removal in oceanic sediments and the oceanic U balance. Earth Planet. Sci. Lett., 97, 94-101.

Basu, A. R., Jacobsen S. B., Poreda R. J., Dowling C. B. and Aggarwal P. K (2001) Large groundwater strontium flux to the oceans from the Bengal Basin and the marine strontium isotope record. Science 293, 1470-1473.

Boyle E., Collier R. Dengler A., Edmond, J. M. Ng, A. C., and Stallard, R. F. (1974) Chemical mass balance in estuaries. Geochim. Cosmochim. Acta, 38, 1719-1728.

Burnett W. C., Taniguchi M and Oberdorfer J. (2001) Measurement and significance of the direct discharge of groundwater into the coastal zone. J. Sea Res. 46, 109-116.

Burnett W., Chanton J., Christoff J., Kontar E., Krupa S. et al. (2002) Assessing methodologies for measuring groundwater discharge to the ocean. EOS. 83, 117, 122, 123.

Burnett, W.C., Bokuniewicz, H., Huettel, M., Moore, W.S., and Taniguchi, M. (2003) Groundwater and pore water inputs to the coastal zone, Biogeochem., 66, 3-33.

Cambareri T.C. and Eichner E.M. (1998) Watershed delineation and ground water discharge to a coastal embayment, Ground Water 36, 626-634.

Charette, M.A., Sholkovitz, E.R., and Hansell, C.M. (2005) Trace element cycling in a subterranean estuary: Part 1. Geochemistry of the permeable sediments. Geochim. Cosmochim, Acta, 69, 2095-2109. 
Charette, M.A., Splivallo, R., Herbold, C., Bollinger, M., and Moore, W.S. (2003) Salt marsh submarine groundwater discharge as traced by radium isotopes, Mar. Chem., 84, 113121.

Charette M. A. and Sholkovitz E. R. (2002) Oxidative precipitation of groundwater-derived ferrous iron in the subterranean estuary of a coastal bay. Geophy. Res. Lett. 29, 10.1029/2001GL014512.

Charette M.A., Buesseler K.O. and Andrews, J.E. (2001) Utility of radium isotopes for evaluating the input and transport of groundwater-derived nitrogen to a Cape Cod estuary. Limnol. Oceanogr. 46, 465-470.

Chen, J. H., R.L. Edwards, and G.J. Wasserburg (1986) ${ }^{238}$ U, ${ }^{234} \mathrm{U}$, and ${ }^{232} \mathrm{Th}$ in seawater. Earth Plantary Sci. Lett., 80, 241-251.

Cochran, J. K., N. H. Landman, K. K. Turekian, A. Michard and D. P. Schrag (2003). Paleoceanography of the Late Cretaceous (Maastrichtian) Western Interior Seaway of North America: evidence from $\mathrm{Sr}$ and $\mathrm{O}$ isotopes, Palaeogeo., Palaeoclimatol., Palaeoecol., 191, 45-64.

Cochran, J. K., Carey A. E., Sholkovitz E. R. and Surprenant L. D. (1986) The geochemistry of uranium and thorium in coastal marine sediments and sediment pore waters. Geochim. Cosmochim. Acta, 50, 663-680.

Cochran, J.K. (1982) The oceanic chemistry of the $U$ and Th series nuclides. In Uranium series disequilibrium: Application to environmental problems (Ivanivich, M.; Harmon, R.S.: editors). Clarendon Press, p. 384-435. Oxford.

Coffrey M., Dehairs F., Collette O., Luther G., Church T. and Jickells T. (1996) The behavior of dissolved barium in estuaries. Estuar. Coast. Shelf Sci. 45, 113-121. 
Cowart, J.B. (1980) The relationship of uranium isotopes to oxidation-reduction in the Edwards carbonate aquifer of Texas, Earth Planet. Sci. Lett., 48, 277-283.

DeLange G. J., Catalano G., Klinkhammer G. P. and Luther, G. W. III. (1990) The interface between oxic seawater and the anoxic Bannock brine; its sharpness and the consequences for the redox-related cycling of Mn and Ba. Mar. Chem. 31, 205-217.

Drever, J. I. (1988). The Geochemistry of Natural Waters (2nd ed.). London: Prentice-Hall.

Duncan, T., and Shaw, T.J. (2003) The mobility of rare earth elements and redox sensitive elements in the groundwater/seawater mixing zone of a shallow coastal aquifer, Aquat. Geochem., 9, 233-255.

Dunk, R.M., Mills, R.A., and Jenkins, W.J. (2002) A reevaluation of the oceanic uranium budget for the Holocene, Chem. Geol., 190, 45-67.

Ganeshram, R.S., François, R., Commeau, J., and Brown-Leger, S.L. (2003) An experimental investigation of barite formation in seawater, Geochim. Cosmochim. Acta, 67, 2599-2605.

Hanor J. S. and Chan L. H. (1977) Non-conservative behavior of barium during the mixing of Mississippi River and Gulf of Mexico waters. Earth Planet. Sci. Lett., 37, 242-250.

Koide, M. and Goldberg, E.D. (1963) Uranium-234/uranium-238 ratios in sea water, Prog. Oceanogr., 3, 173-177.

Li Y.-H. and Chan L. (1979) Desorption of Ba and ${ }^{226}$ Ra from river-borne sediments in the Hudson estuary. Earth Planet. Sci. Lett. 43, 343-350.

McGrath, M., Davison W. and Hamilton-Taylor J. (1989) Biogeochemistry of barium and strontium in a softwater lake. Science of the Total Environment. 87/88, 287-295. 
Michael H.A., Lubetsky J. S. and Harvey C. F. (2003) Characterizing submarine groundwater discharge: A seepage meter study in Waquoit Bay, Massachusetts. Geophys. Res. Lett. 10.1029/2002GL016000.

Mishra S. P. and Tiwary D. (1993) Radiotracer technique in adsorption studies. X. Efficient removal of $\mathrm{Ba}$ (II) from aqueous solutions by hydrous manganese oxide. J. Radioanaly. Nuclear Chem. 170, 133-141.

Moore, W.S. (1996) Large groundwater inputs to coastal waters revealed by ${ }^{226} \mathrm{Ra}$ enrichments. Nature 380, 612-614.

Moore, W. S. (1997) High fluxes of radium and barium from the mouth of the GangesBrahmaputra River during low river discharge suggest a large groundwater source. Earth Planet. Sci. Lett., 150, 141-150.

Moore, W.S. (1999) The subterranean estuary: a reaction zone of ground water and sea water, Mar. Chem. 65, 111-125.

Moore W. S. and Shaw T. J. (1998) Chemical signals from fluid advection onto the continental shelf. J. Geophy. Res. 103, 21543-21552.

Moore, W. S., and Reid, D.F. (1973) Extraction of radium from natural waters using manganeseimpregnated acrylic fibers. J. Geophys. Res., 90, 6983-6994.

Ouyang, Y, Shinde, D, Mansell, R.S., and Harris, W. (1996) Colloid-enhanced transport of chemicals in subsurface environments: A review. Crit. Rev. Environ. Sci. Tech. 26, 189204.

Pilson, M.E.Q. (1998) An Introduction to the Chemistry of the Sea, New Jersey: Prentice Hall. 
Rogers, J.R., and Bennett, P.C. (2004) Mineral stimulation of subsurface microorganisms: release of limiting nutrients from silicates, Chem. Geol., 203, 91-108.

Rushdi, A.I., McManus, J. and Collier R.W. (2000) Marine barite and celestite saturation in seawater, Mar. Chem., 69, 19-31.

Shaw T. J., Sholkovitz E. R. and Klinkhammer G. (1994) Redox dynamics in the Chesapeake Bay: The effect on sediment/water uranium exchange. Geochim. Cosmochim. Acta, 58, 2985-2995.

Shaw T. J., Moore W. S., Kloepfer J. and Sochaski M. (1998) The flux of barium to the coastal waters of the southeastern USA: the importance of submarine groundwater discharge. Geochim. Cosmochim. Acta 62, 3047-3054.

Sholkovitz, E. R. (1985). Redox-related geochemistry in lakes: Alkali metals, alkaline-earth elements and ${ }^{137}$ Cs. In: Chemical Processes in Lakes (W. Stumm, ed.), Wiley Press, pp. $119-142$.

Sholkovitz E., Herbold C. and Charette M. (2003) An automated dye-dilution based seepage meter for the time-series measurement of submarine groundwater discharge. Limnol. Oceanogr.: Methods 1, 16-28.

Stookey L. L. (1970) Ferrozine - a new spectrometric reagent for iron. Anal. Chem 42, 779-781.

Sugiyama M., Hori T., Kihara S. and Matsui M. (1992) A geochemical study of the specific distribution of barium in Lake Biwa, Japan. Geochim. Cosmochim. Acta 56, 597-605.

Swarzenski, P. Campbell, P., Porcelli, D. and McKee, B. (2004) The estuarine chemistry and isotope systematics of ${ }^{234,238} \mathrm{U}$ in the Amazon and Fly Rivers, Cont. Shelf Res., 24, 23572372. 
Swarzenski, P.W. and McKee, B.A. (1998) Seasonal uranium distributions in the coastal waters off the Amazon and Mississippi Rivers. Estuaries. 21, 379-390.

Swarzenski, P.W., McKee, B.A., and Booth, J.G. (1995) Uranium geochemistry on the Amazon Shelf - Chemical-phase partitioning and cycling across a salinity gradient. Geochim. Cosmochim. Acta 59, 7-18.

Tonkin, J. W., Balistrieri L. S., and Murray J. W. (2004) Modeling sorption of divalent metal cations on hydrous manganese oxide using the diffuse double layer model. Applied Geochem. 19, 29-53.

U.S. Geological Survey (2003) Ground Water in Freshwater-Saltwater Environments of the Atlantic Coast: P.M. Barlow, Ed., U.S. Geological Survey Circular 1262, 113 p.

Valiela I., Costa J., Foreman K., Teal J. M., Howes B. and Aubrey D. (1990) Transport of groundwater-borne nutrients from watersheds and their effects on coastal waters. Biogeochem. 10, 177-197.

Windom H. and Niencheski F. (2003) Biogeochemical processes in a freshwater-seawater mixing zone in permeable sediments along the coast of Southern Brazil. Mar. Chem. 83, $121-130$.

Windom, H., Smith, R., Niencheski F., and Alexander C. (2000) Uranium in rivers and estuaries of globally diverse, smaller watersheds. Mar. Chem., 68, 307-321. 


\section{Figure Captions}

Figure 1. Waquoit Bay on Cape Cod, MA. USA. The mouth at the southern end of the Bay opens to Vineyard Sound. The Bay is approximately $3 \mathrm{~km}$ long and $1 \mathrm{~km}$ wide and has mean water depth of $1 \mathrm{~m}$. The expanded location map for the head of the Bay shows the piezometercollected pore water profiles discussed in this paper. Profiles were collected along shore perpendicular (A-A') and shore parallel (B-B') transects in July 2002. PZ1 was located $50 \mathrm{~m}$ to the east of its location on the map. PZ9 (not shown) was located $25 \mathrm{~m}$ to the east of PZ4.

Figure 2. Two-dimensional contours of pore water salinity (a), dissolved Fe (b), and dissolved Mn (c) in the subterranean estuary at the head of Waquoit Bay. The data were collected from the six piezometer stations along the A-A' shore-perpendicular transect in Figure 1. The piezometer station numbers for each profile are located along the top edge of the figure.

Figure 3. Two-dimensional contours of pore water salinity (a), dissolved Ba (b), and dissolved U (c) in the subterranean estuary at the head of Waquoit Bay. The data were collected from the six piezometer stations along the A-A' shore-perpendicular transect in Figure 1. The piezometer station numbers for each profile are located along the top edge of the figure.

Figure 4. Pore water profiles of salinity, dissolved Fe, Mn, Ba, Sr, and $\mathrm{U}$ for (a) piezometer \#3 (PZ3) and (b) piezometer \#7 (PZ7) along the A-A' shore-perpendicular transect. PZ7 is located primarily in the freshwater zone of the subterranean estuary. PZ3 covers the whole salinity gradient. The shaded region in (a) represents the salinity transition zone (STZ).

Figure 5. A comparison of pore water and surface water concentrations of dissolved Ba. (a) Pore water concentrations of barium versus salinity for all piezometer samples collected during July 2002. The dashed line indicates the saturation line for barium with respect to barite (barium sulfate) formation (Rushdi et al., 2000). The solid line indicates the effective zero salinity endmember for the PZ3 Ba data only. (b) Surface water Ba vs. salinity and the interpolated concentration of $\mathrm{Ba}$ at zero salinity. 
Figure 6. Dissolved Sr vs. salinity for the PZ3 pore water profile and for three Bay water samples collected in 1999. The solid line indicates the conservative mixing line between the fresh groundwater and open ocean end member. The dashed line indicates the effective zero salinity endmember.

Figure 7. A comparison of pore water and surface water concentrations of dissolved U. (a) Pore water uranium versus salinity for all piezometer samples collected during July 2002. Also shown is the Bay water U collected during 1999. The dashed line indicates the conservative mixing line for U in seawater (Chen et al., 1986). (b) Expanded U-salinity distribution plot for the surface waters and the interpolated concentration of $U$ at zero salinity.

Figure 8. Barium versus dissolved $\mathrm{Mn}$ and barium for the middle three piezometers along the A$\mathrm{A}^{\prime}$ transect (PZ3, PZ6 and PZ8). 


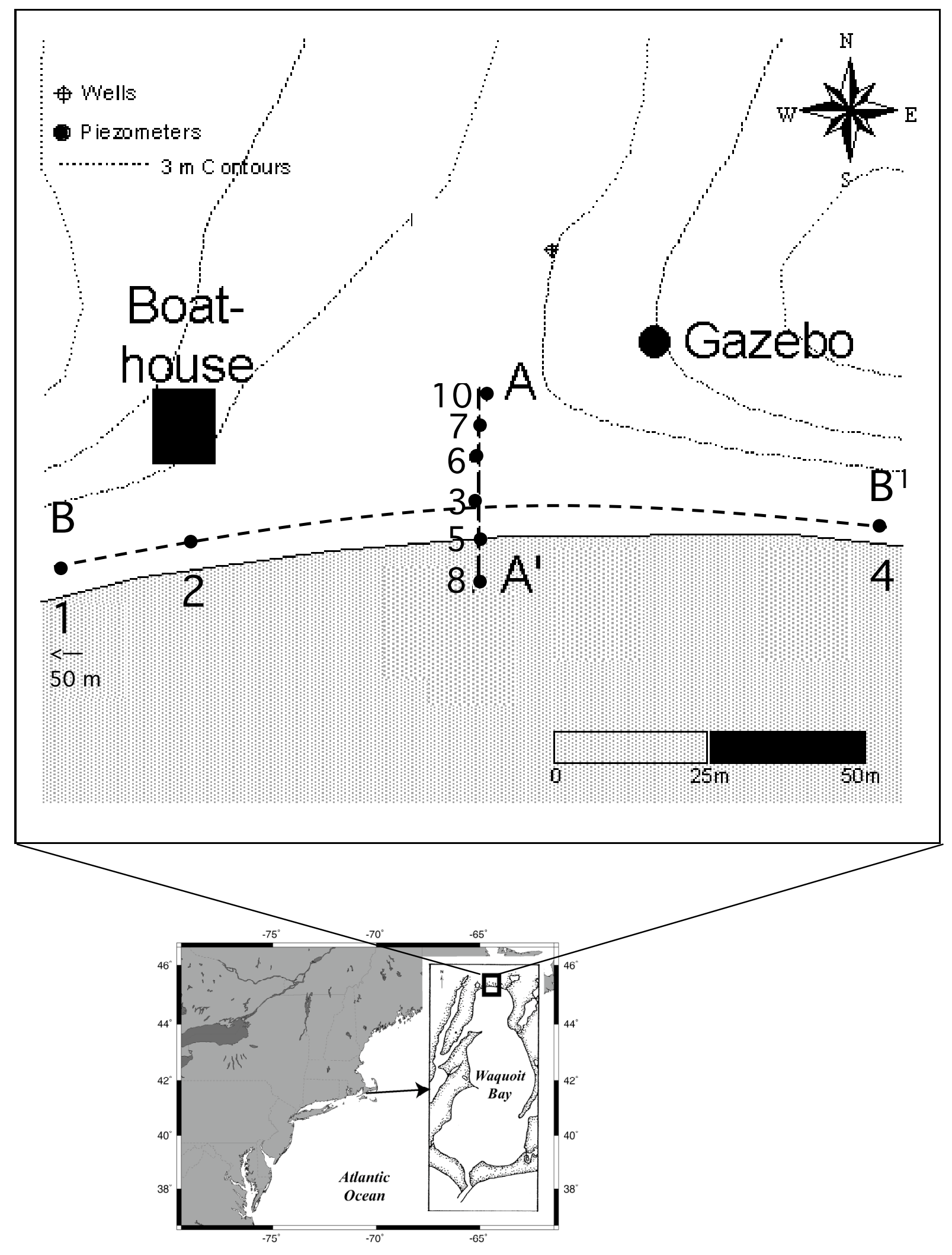

Figure 1 


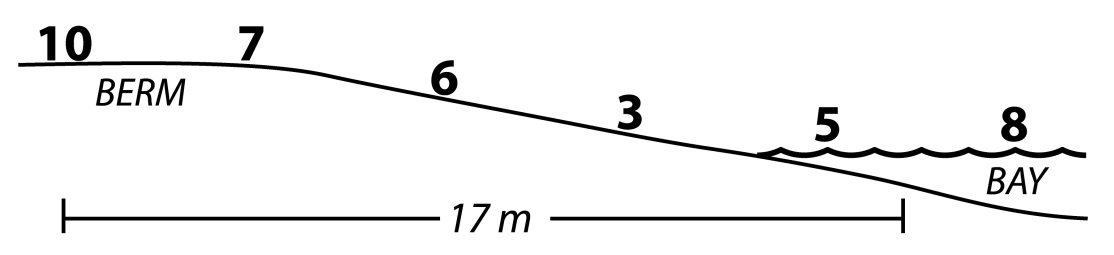

a)

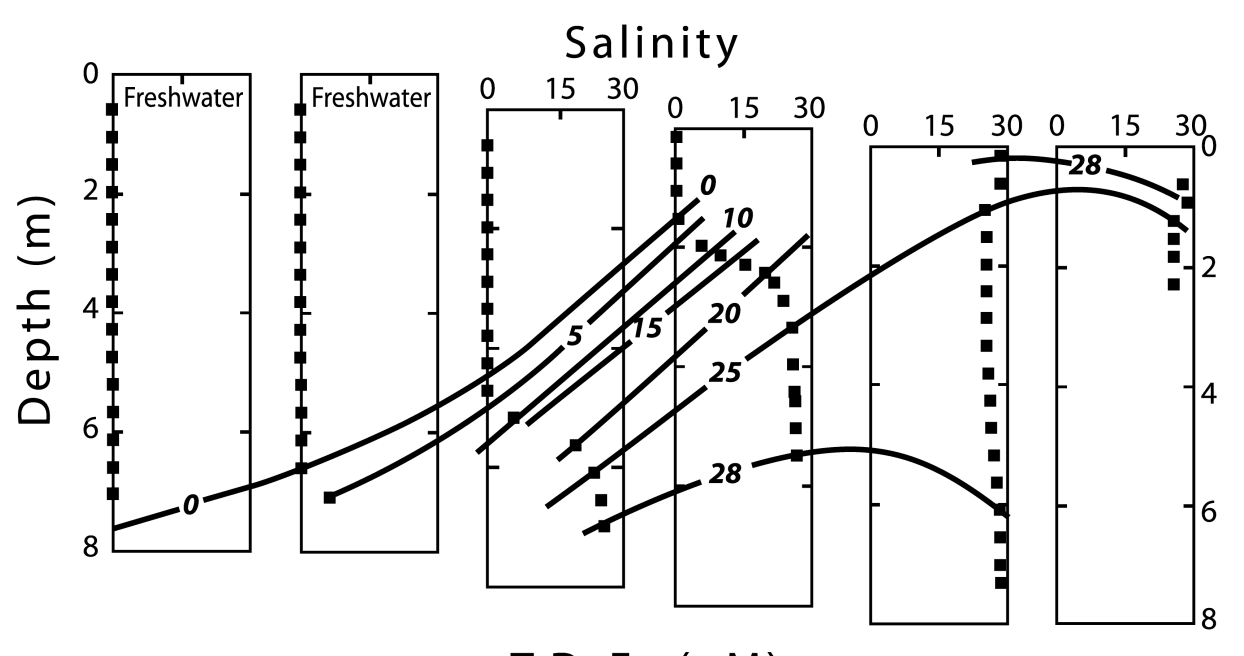

b)
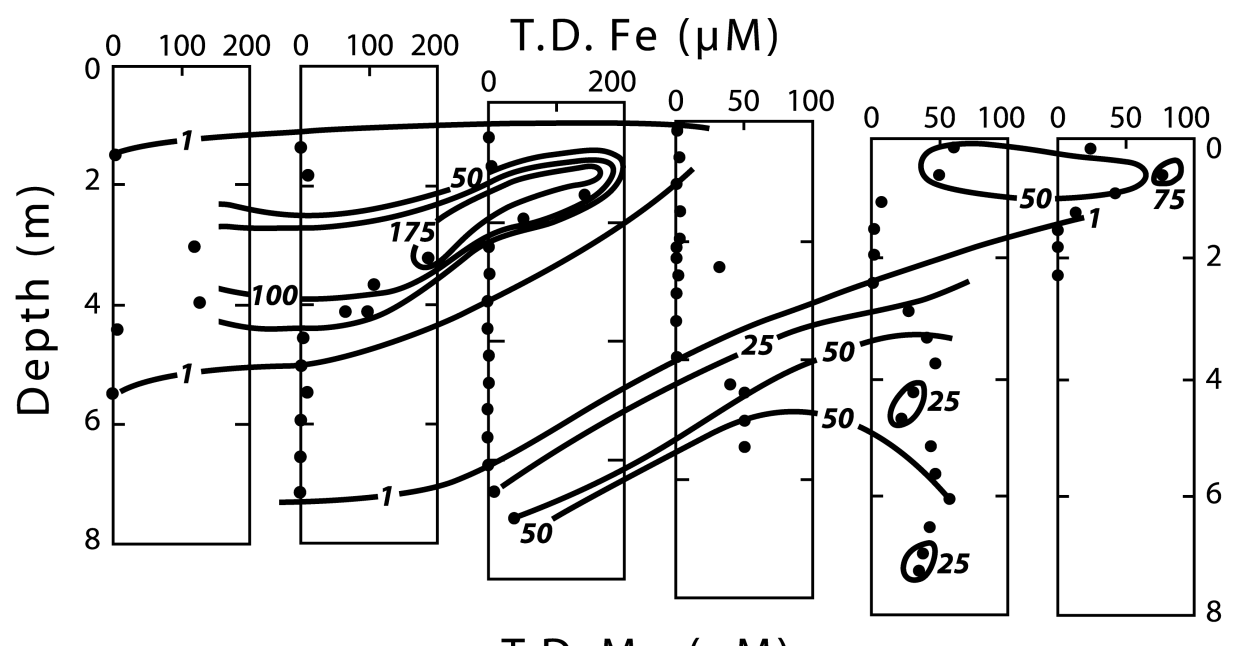

c)

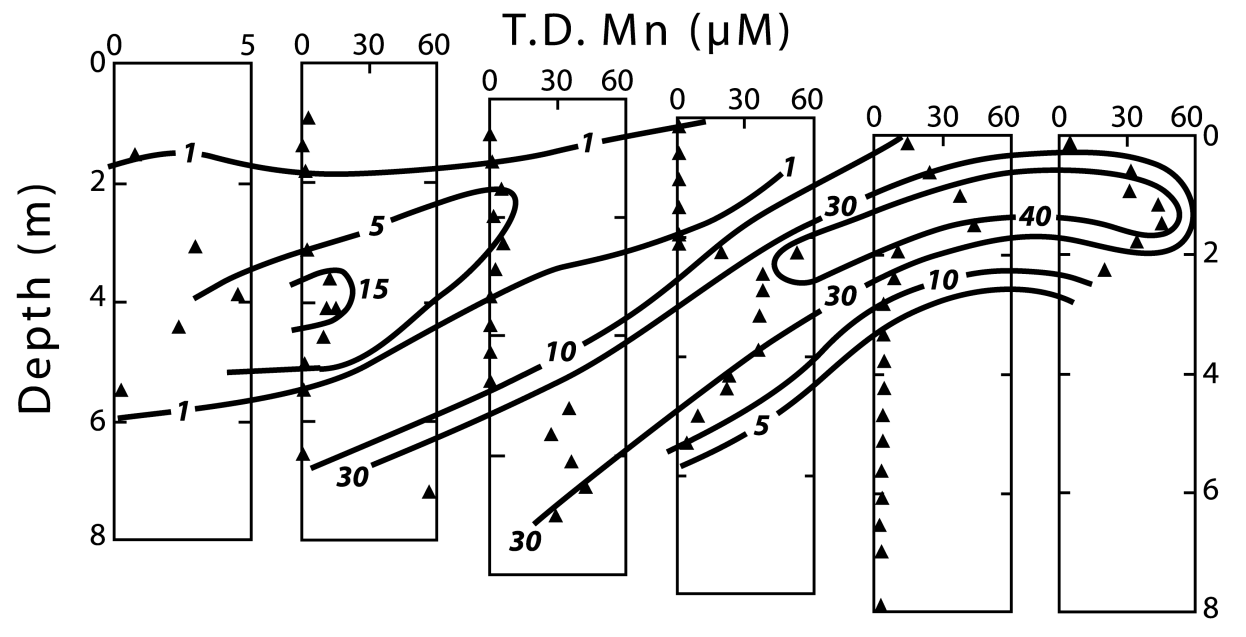

Figure 2 

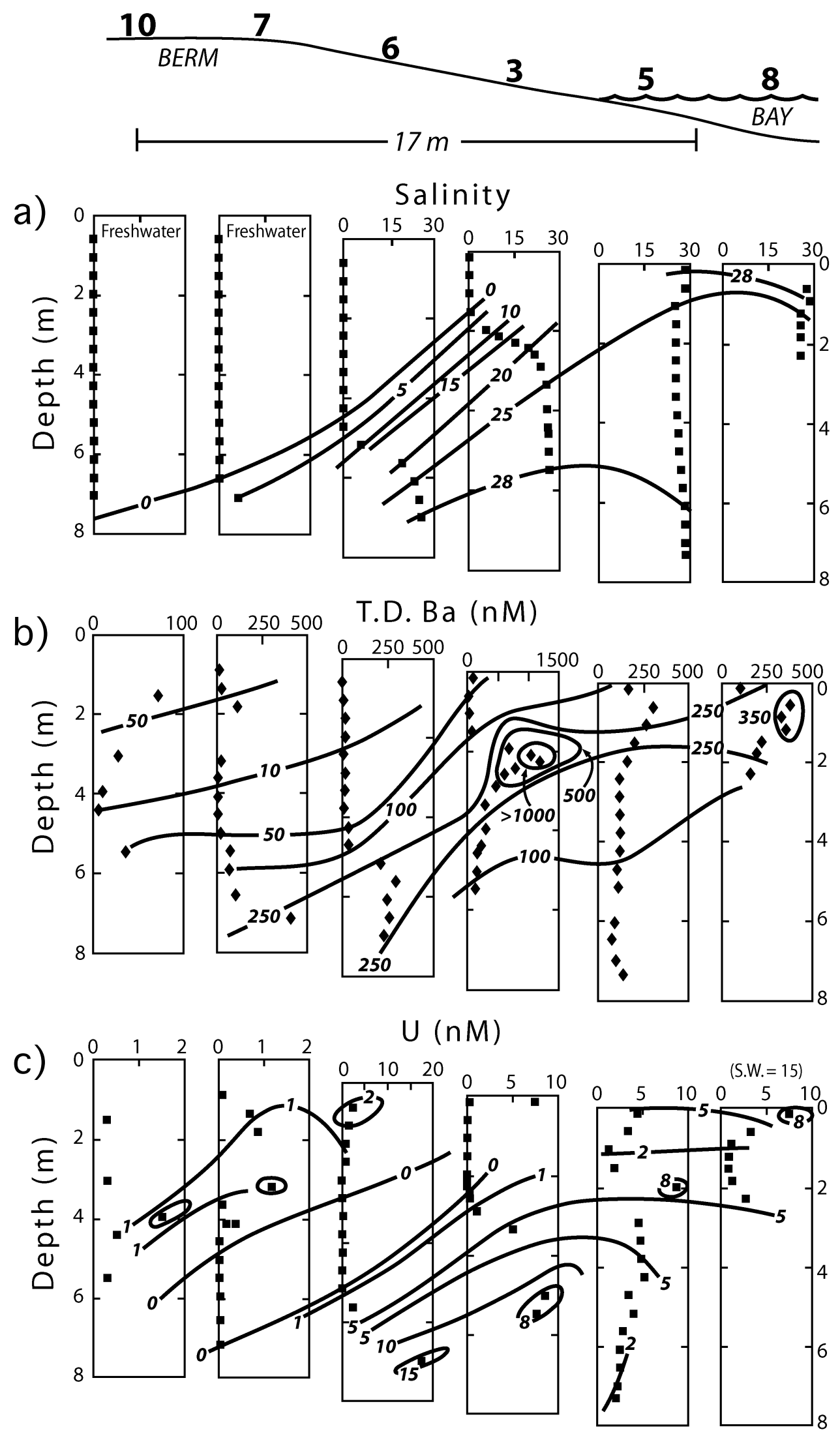

Figure 3 


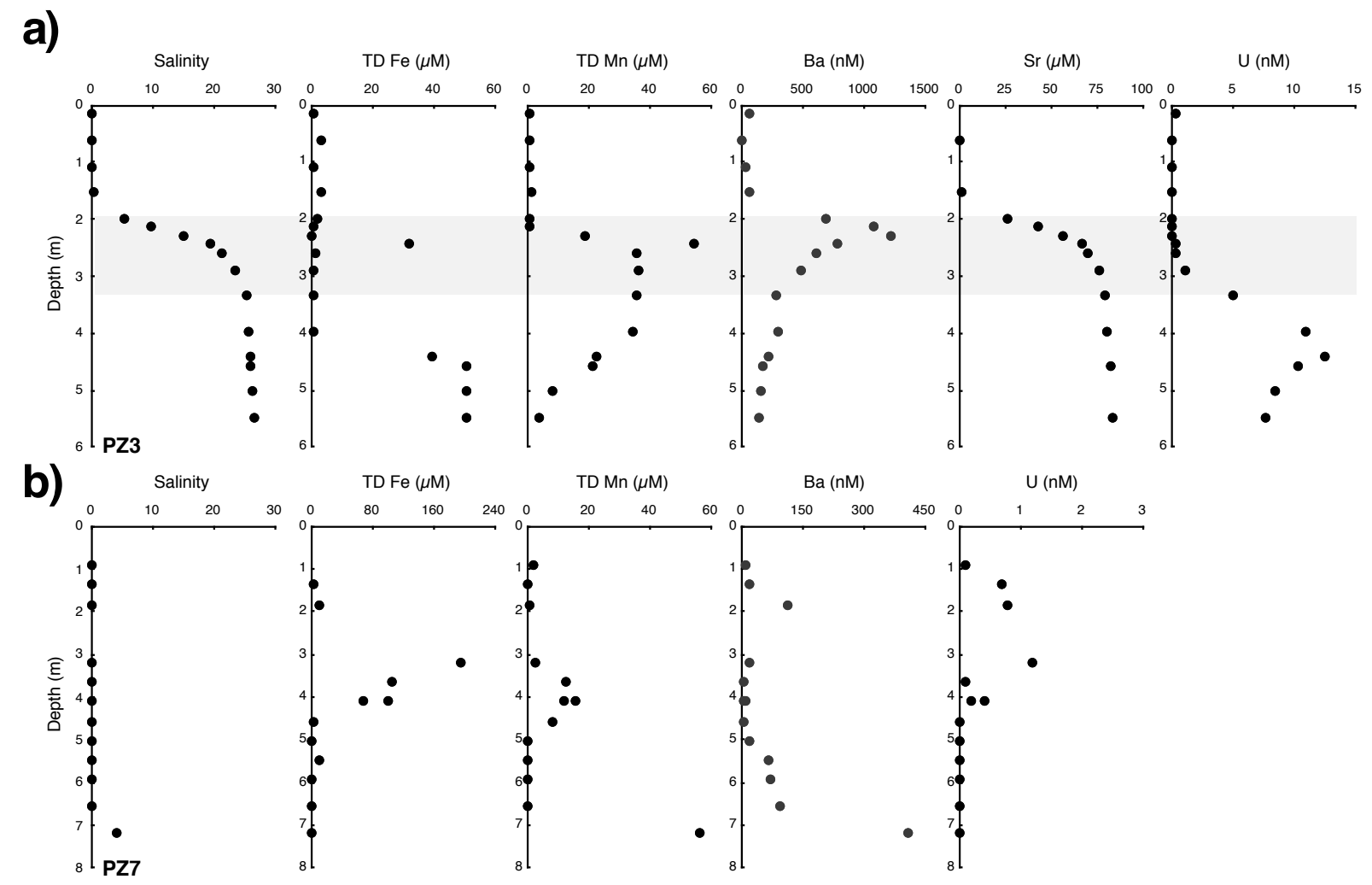

Figure 4 

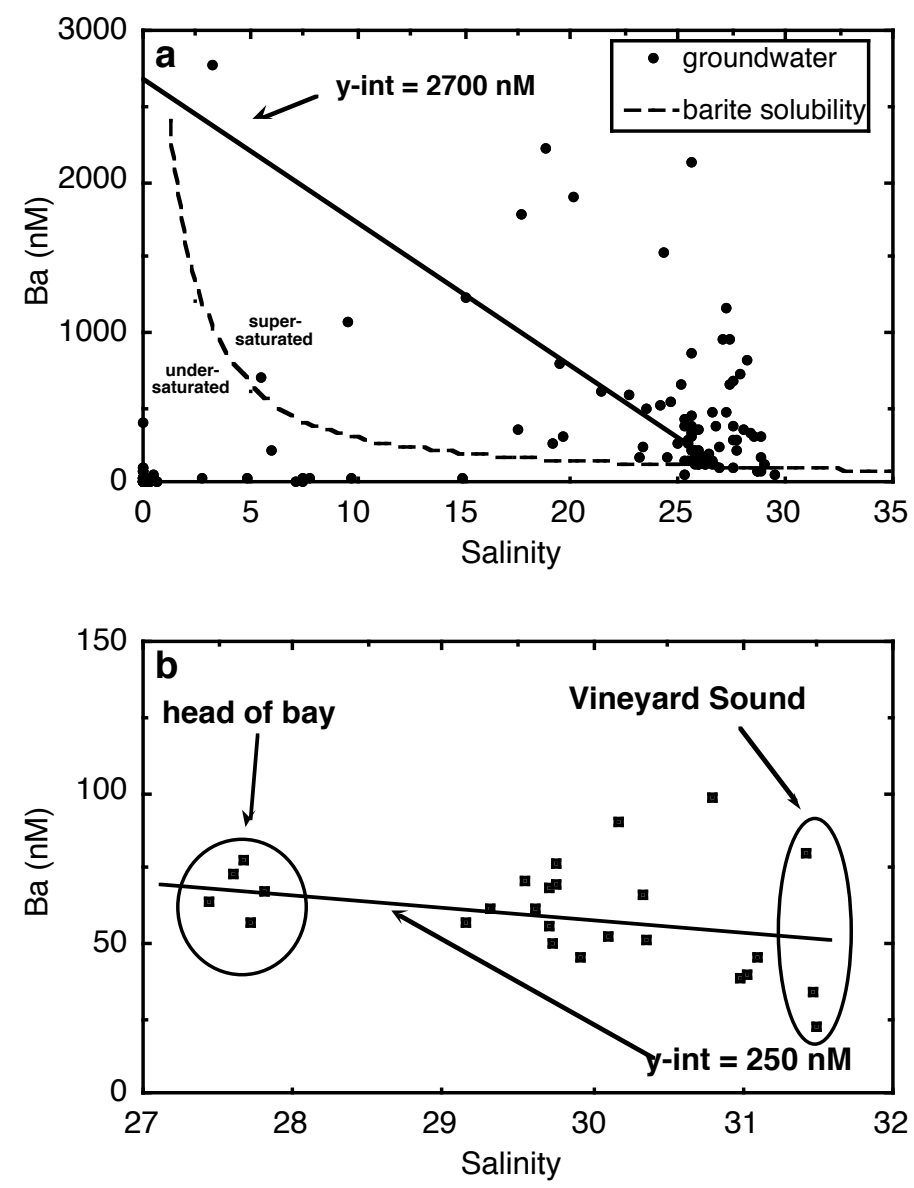

Figure 5 


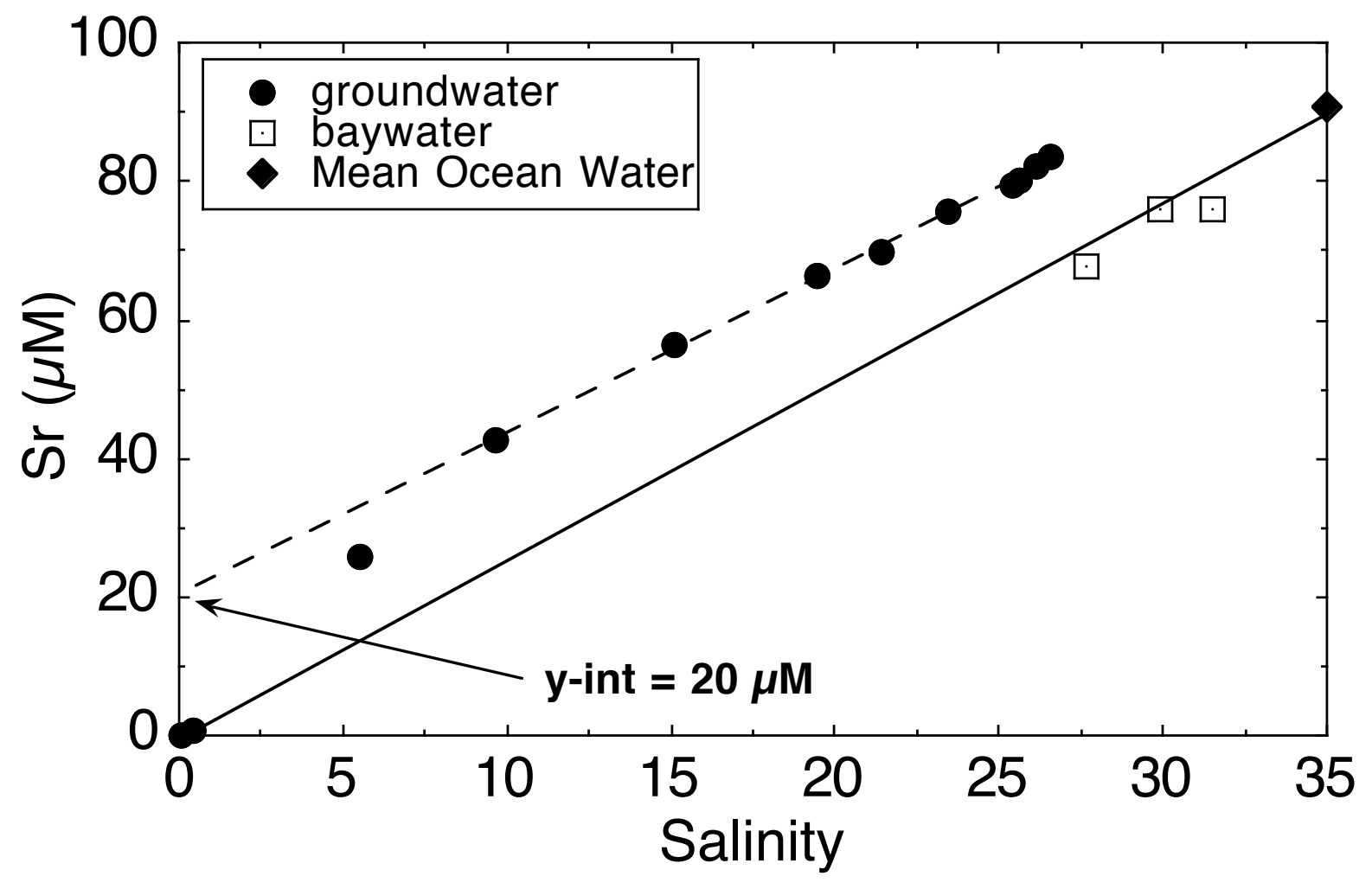

Figure 6 

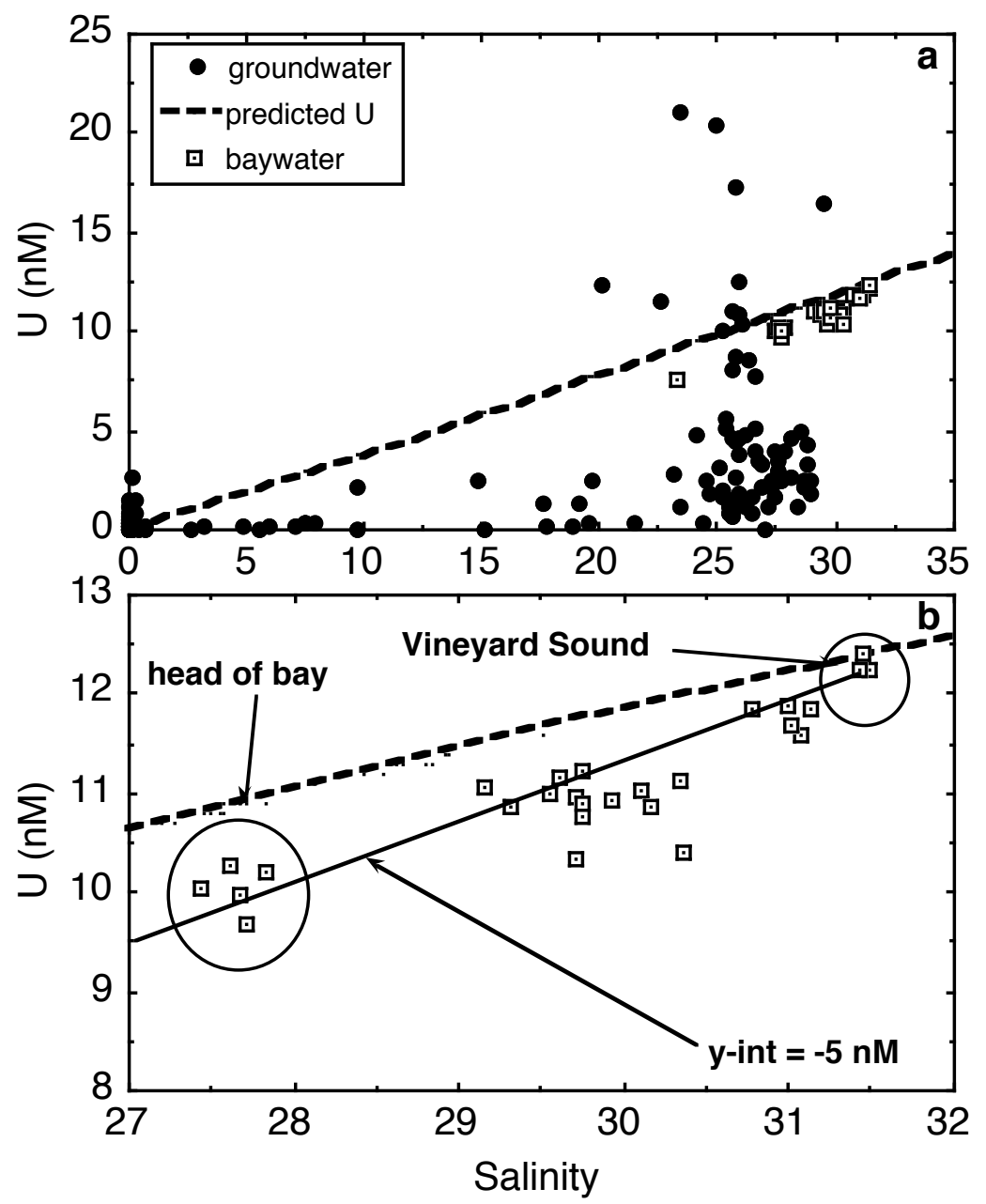

Figure 7 


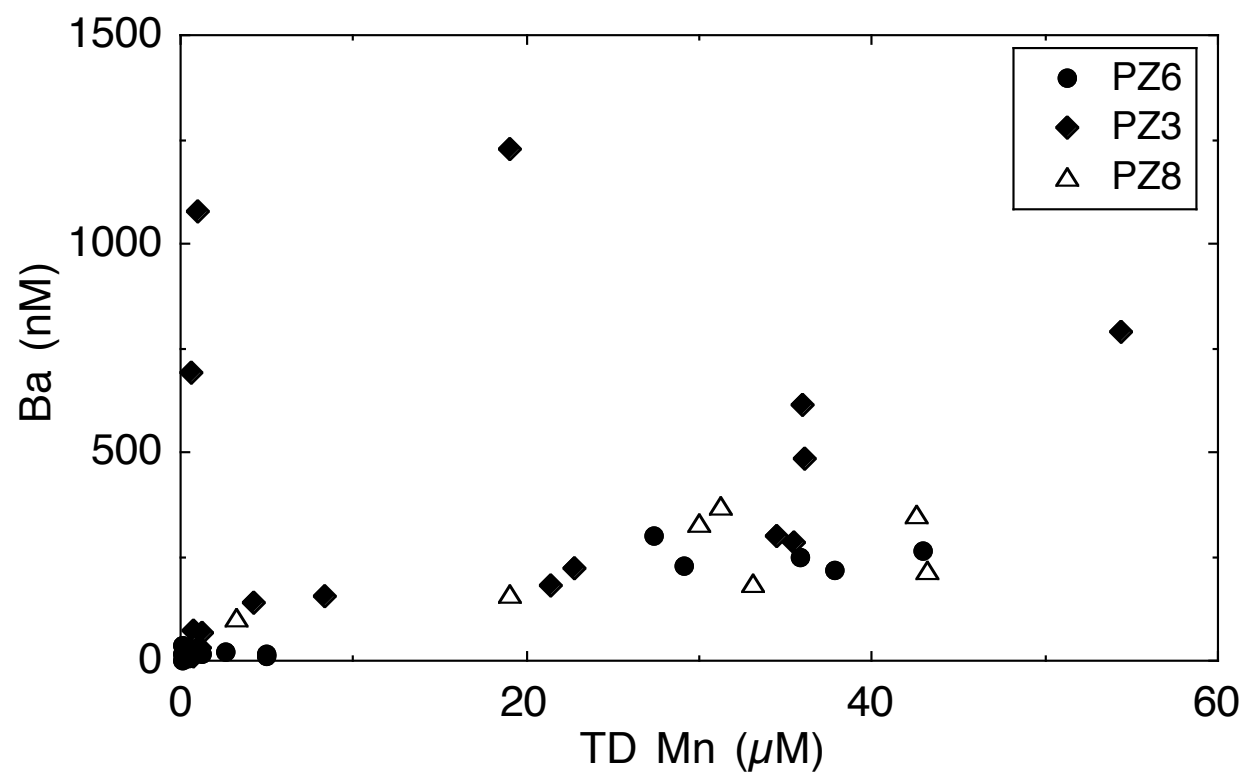

Figure 8 